\title{
Identifying Soybean Rust-resistant and Susceptible Populations of Kudzu to Increase Disease Monitoring Efficiency in Alabama
}

\begin{abstract}
Edward J. Sikora and Mary A. Delaney, Department of Entomology and Plant Pathology, Alabama Cooperative Extension System, Auburn University, AL 36949
\end{abstract}

Accepted for publication 24 October 2016.

\section{ABSTRACT}

Soybean rust (SBR), caused by Phakopsora pachyrhizi, is considered to be one of the most damaging diseases of soybean worldwide. Monitoring for the disease in Alabama relies heavily on scouting kudzu on a biweekly basis in south and central portions of the state from late January through the end of July in areas where soybean production is minimal and is critical to help growers avoid significant yield losses from SBR. Previous studies have reported that some kudzu populations are naturally resistant or immune to infection from the pathogen which can complicate early disease

\section{INTRODUCTION}

Soybean rust (SBR), caused by Phakopsora pachyrhizi Sydow, has been a recurring problem for soybean (Glycine max Merrill) growers in the southern United States since it was first reported in 2004 (Schneider et al. 2005; Sikora and Hershman 2008). The disease was a significant problem in Alabama in 2012 when SBR reduced yield by over $60 \%$ in over 500 acres of poorly managed soybean in the southern region of the state (Sikora et al. 2013; Sikora et al. 2014a). Fields with the greatest yield losses either received a fungicide application too late or failed to receive a fungicide. Estimated economic losses were upwards of $\$ 135,000$ to farmers who failed to apply a fungicide during the 2012 season (Alabama Cooperative Extension System 2013; Allen et al. 2014). Significant damage from SBR was also observed in 2013 where losses of up to $40 \%$ were estimated in unprotected or poorly protected fields (Allen et al. 2014; Sikora et al. 2014b). Greater losses appear to have been avoided with properly timed fungicide applications based on management suggestions strengthened by regional scouting for the disease.

\section{KUDZU GONE WILD}

Kudzu (Pueraria montana var. lobata (Willd) Sanjappa \& Predeepis) is a semi-woody perennial climbing vine first introduced into the United States in 1876 as an ornamental plant (Everest et al. 1999; Miller and Edwards 1983). In the early 1900s, kudzu was promoted as an inexpensive forage crop for livestock, but reached its greatest level of prominence in the 1930s when it was widely planted in the southern United States to control soil erosion (Britton et al. 2002). Kudzu has been observed in 31 states and Ontario, Canada, and is estimated to cover over 7.4 million acres of the eastern United States (Sikora

Corresponding author: Edward J. Sikora. Email: sikorej@auburn.edu.

doi:10.1094/PHP-RS-16-0039

(C) 2016 The American Phytopathological Society detection. This study will apply that knowledge to determine locations of kudzu populations that are either resistant or susceptible to $P$. pachyrhizi in order to increase monitoring efficiency and reduce costs associated with the scouting program. Results show that approximately $34 \%$ of the 162 kudzu sites tested in Alabama were resistant to P. pachyrhizi. By focusing scouting efforts on SBRsusceptible kudzu sites, we will reduce costs associated with the monitoring program by approximately $25 \%$ which is critical at a time when funding for such efforts is decreasing.

2014). The major concentration of kudzu is in the southern United States, where some states (e.g., Alabama, Georgia, and North Carolina) report every county to be infested with the invasive weed (Allen et al. 2014).

Kudzu, a close relative of soybean, is now considered the primary overwintering host of $P$. pachyrhizi in the United States, and important to the potential for SBR epidemics in this country (Sikora 2014a; Sun et al. 2005). Soybean rust-infected kudzu leaves that survive the winter and new kudzu leaves that are infected prior to soybean emergence in the spring serve as a bridge for SBR inoculum increase and northward spread (Sikora 2014). SBR has successfully overwintered on kudzu in Alabama in eight of the past 11 years as well as on kudzu in Florida and Louisiana along the Gulf coast in most years since 2006. These

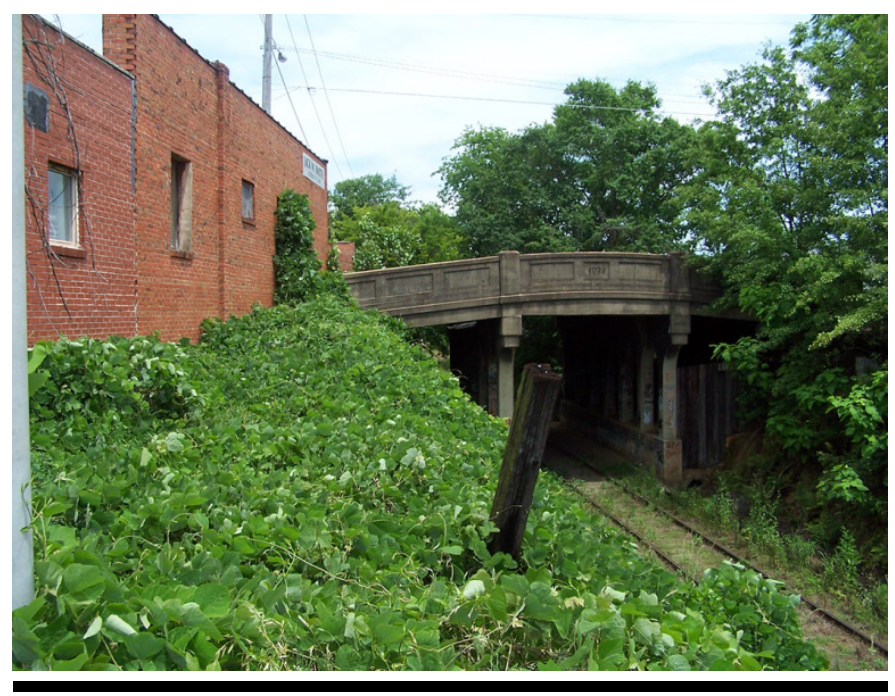

FIGURE 1

The perennial weed kudzu growing next to an abandoned building and along a railroad track in Dothan, AL. 
sites are almost always associated with urban heat islands in cities or towns that experience elevated temperatures compared to outlying rural areas (Oke 1997; Sikora 2014). Some of these infected kudzu sites have been identified as far north as the cities of Montgomery and Selma in central Alabama (Sikora 2014).

\section{WHY SCOUT KUDZU FOR SOYBEAN RUST?}

The Alabama SBR monitoring program was started in 2005 shortly after the disease was first detected in the state (Mullen et al. 2006; Sikora et al. 2009). The program is part of the Soybean Rust-Pest Information Platform for Extension and Education which relies on real-time disease monitoring information to track and predict in-season spread of the pathogen in North America (Giesler and Hershman 2005; Hershman et al. 2011; Sikora et al. 2014a). The program includes monitoring soybean sentinel plots as well as kudzu sites early in the year before the majority of commercial soybean fields have reached reproductive stages of plant growth to aid in early detection of the disease. In Alabama, monitoring of kudzu typically focuses on large patches in rural areas often along county roads that are accessible to scouts and where kudzu growth often goes unchecked by landowners (Figs. 1 to 3). Typically, kudzu populations, selected randomly by scouts, are monitored biweekly from late January through the end of July in south Alabama, covering a 24-week period. Eventually, kudzu monitoring becomes statewide as the season moves into the late summer/fall period, and as SBR begins to spread northward through the state. In Alabama, kudzu is the sole monitoring host throughout much of the southern third of the state because of the lack of commercial soybean production in this region (Price 2016) and the lack of suitable locations for establishing soybean sentinel plots. Therefore, the ability to scout kudzu is a vital component of the SBR monitoring program in Alabama.

Scouting kudzu consists of visiting multiple kudzu sites in an area and examining a minimum of 100 leaflets per site. In any given day, a scout may examine 25 to 30 sites in 10 to 12 counties for SBR. This method of scouting is laborious, time consuming and costly because there is so much kudzu and too few scouts. Another confounding aspect of kudzu is that some sites are naturally resistant or immune to infection from the fungus (Bonde et al. 2009; Jordan et al. 2010). This fact suggests that field scouts, who often pick kudzu sites arbitrarily, have likely surveyed patches that were resistant or immune to the disease.

The purpose of this study was to determine if kudzu sites frequently used for monitoring for SBR in southern Alabama were susceptible or resistant to $P$. pachyrhizi. Determining the exact location of kudzu sites that are susceptible to the disease will enable scouts to focus their efforts on kudzu populations more likely to exhibit early symptoms of the disease. Mapping susceptible kudzu populations could then be used as a guide for future scouts to focus their efforts on susceptible kudzu sites and to avoid resistant populations in order to save time and money.

\section{TESTING KUDZU TO DETERMINE RESISTANCE TO SOYBEAN RUST}

South and central Alabama kudzu sites located along roadways in rural areas, and historically used by scouts to monitor for SBR, were chosen. Criteria used for selecting individual sites included: heavily shaded areas that would promote environmental conditions conducive for SBR development; ease of access, including a wide shoulder or a driveway to park vehicles for the safety of scouts from on-coming traffic; and areas that offered some security from aggressive dogs, poisonous snakes, suspicious land- owners, and the occasional kudzu-hidden ditch or ravine. The latitude and longitude for each site was determined and a physical description of the area was recorded. Kudzu leaves used for the experiment were collected in September and October of each year.

At each site, leaflets with no visible symptoms of SBR were removed from several locations within the patch. The middle leaflet of the 4th or 5th trifoliate leaf from the end of a vine was removed, placed in a plastic bag with a moist paper towel, and transported to the laboratory in an insulated cooler. The leaves were subsequently washed twice with tap water and patted dry with a paper towel. The petioles were recut with a scalpel and the petioles embedded in $1 \%$ water agar in a petri plate (100 by 15 $\mathrm{mm}$ ) with one leaflet per plate. A minimum of five test leaves and two control leaves were used per site.

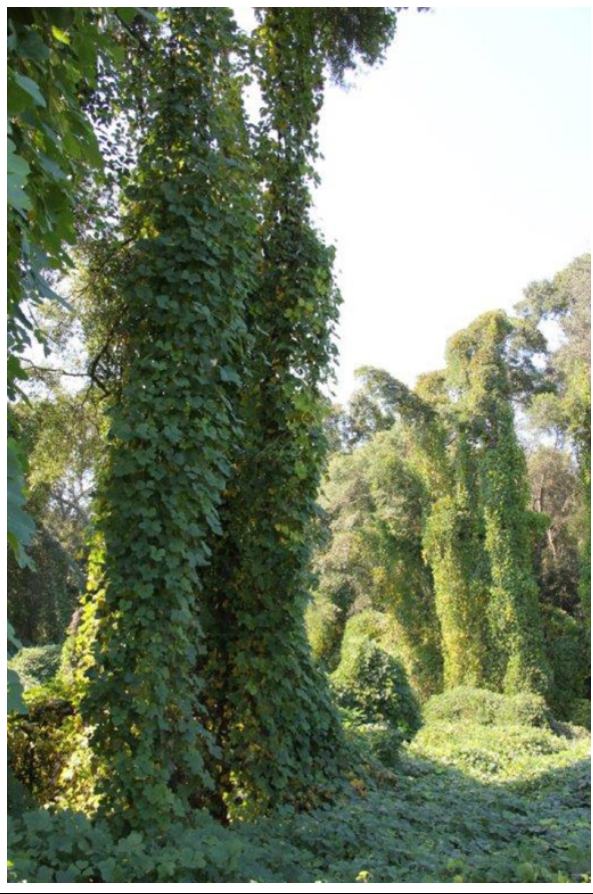

\section{FIGURE 2}

A soybean rust-infected patch of kudzu climbing up trees near Gordon, AL.

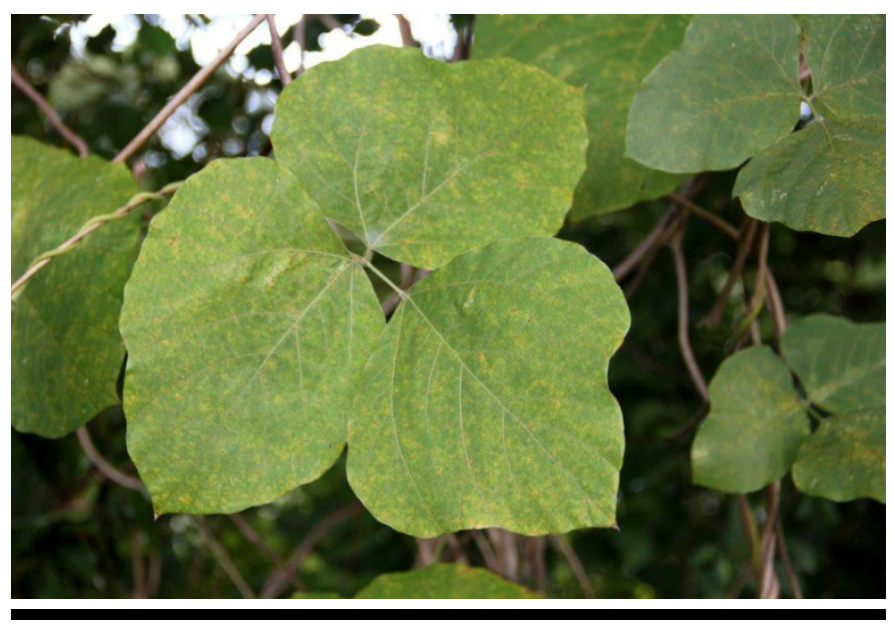

FIGURE 3

Soybean rust-infected leaves in a susceptible kudzu patch in Fairhope, AL. 
Each year, a population of uredinospores of $P$. pachyrhizi was collected from naturally infected soybean plants from soybean sentinel plots located at Auburn University, Auburn, AL (Lee County). A suspension of uredinospores was prepared by brushing spores off infected leaflets using a \#7 paint brush and diluting the resulting spores to $1 \times 10^{8}$ in sterilized distilled water using a hemocytometer. The leaflets were inoculated within $1 \mathrm{~h}$ of preparing the spore suspension. Two leaflets were designated as controls and sprayed with $0.5 \mathrm{ml}$ sterile distilled water. The remaining leaflets were sprayed with $0.5 \mathrm{ml}$ of the uredinospore suspension. The petri plates were covered and allowed to incubate at $23^{\circ} \mathrm{C}$ on the laboratory bench in natural light. Leaves were monitored for lesion development and sporulation of P. pachyrhizi for 28 days after inoculation at which time the test was terminated. Scoring was determined by the presence or absence of pustules with spores on the leaf surface. Sporulation on any leaflets, either inoculated or the controls represented a susceptible reaction by the population being screened (Fig. 4).

\section{KUDZU POPULATIONS RESISTANT TO SOYBEAN RUST DETECTED IN ALABAMA}

A total of 162 kudzu sites from 30 counties in south and central Alabama were screened for resistance to SBR between 2012 and 2015. Results showed that $P$. pachyrhizi was unable to develop on approximately $34 \%$ of the 162 kudzu populations during this period (Table 1). Phakopsora pachyrhizi was not able to develop on $36 \%$ of the 47 populations screened in $2012 ; 38 \%$ of the 73 populations tested in 2013; and on $24 \%$ of the 42 populations screened in 2015. Kudzu screenings were not conducted in 2014 because of the lack of SBR inoculum needed for testing due to the slow progression of the disease within Alabama that year. Attempts were not made to record differences in lesion color, size, or sporulation, and populations were only screened one time during the study period, as the main objective was to identify as

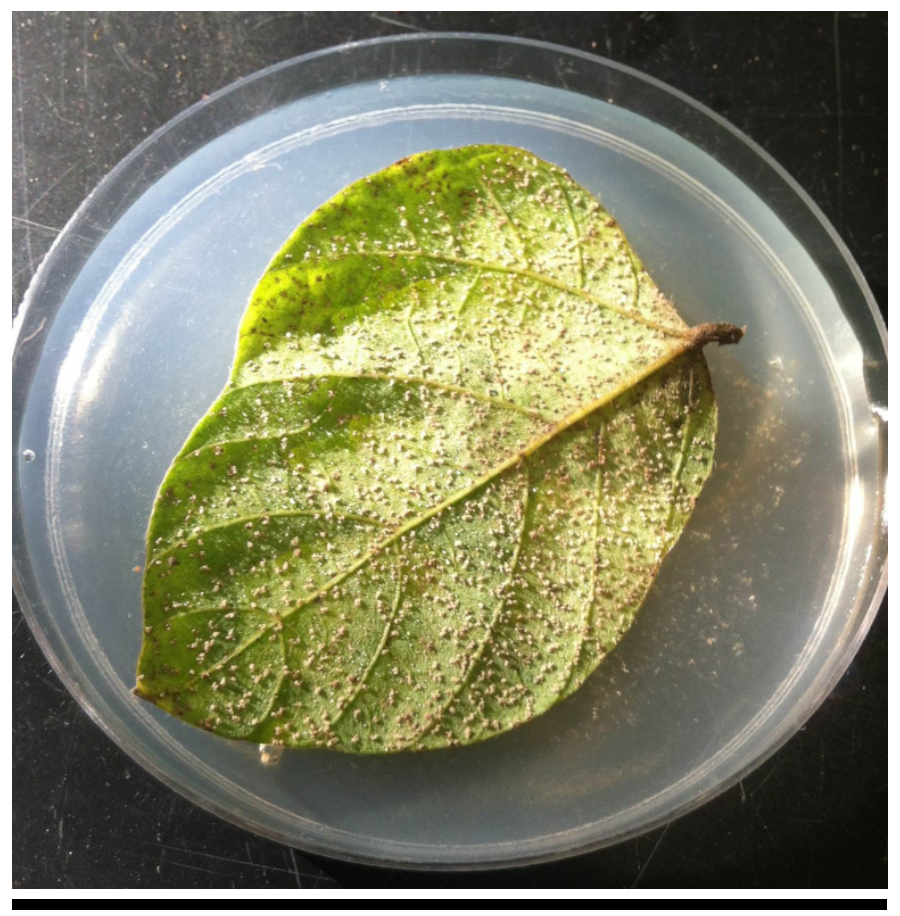

FIGURE 4

Phakopsora pachyrhizi sporulating on inoculated kudzu leaflet exhibiting a susceptible reaction by the host. many susceptible populations of kudzu as possible in the region to aid future scouting efforts.

\begin{tabular}{|c|c|c|c|c|}
\hline \multicolumn{5}{|c|}{$\begin{array}{l}\text { TABLE } 1 \\
\text { County location, year tested, and longitude and latitude of } \\
\text { each kudzu population screened for resistance/ } \\
\text { susceptibility to Phakopsora pachyrhizi and percentage } \\
\text { of leaflets developing pustules with spores on the } \\
\text { leaf surface within } 28 \text { days post-inoculation. }\end{array}$} \\
\hline County & Year & Longitude & Latitude & $\begin{array}{l}\% \text { inoculated } \\
\text { leaflets testing } \\
\text { positive for } \\
\text { P. pachyrhizix }\end{array}$ \\
\hline Baldwin & 2012 & -87.75900 & 30.96762 & 10 \\
\hline Barbour & 2013 & -85.14934 & 31.90994 & 100 \\
\hline Barbour & 2013 & -85.14874 & 31.90431 & 0 \\
\hline Barbour & 2013 & -85.16196 & 31.93298 & 12.5 \\
\hline Barbour & 2013 & -85.18905 & 31.94576 & 0 \\
\hline Barbour & 2013 & -85.23360 & 31.97561 & 12.5 \\
\hline Barbour & 2013 & -85.26073 & 31.98953 & 0 \\
\hline Barbour & 2013 & -85.27923 & 31.99910 & 0 \\
\hline Barbour & 2013 & -85.35558 & 32.02962 & 0 \\
\hline Barbour & 2013 & -85.31453 & 32.01681 & 12.5 \\
\hline Barbour & 2013 & -85.18494 & 31.77153 & 20 \\
\hline Bullock & 2013 & -85.68998 & 32.05811 & 87.5 \\
\hline Bullock & 2012 & -85.71538 & 31.98414 & 50 \\
\hline Bullock & 2013 & -85.70470 & 32.07835 & 100 \\
\hline Butler & 2012 & -86.64416 & 31.86629 & 100 \\
\hline Butler & 2015 & -86.77777 & 31.65241 & 100 \\
\hline Butler & 2012 & -86.84586 & 31.57591 & 0 \\
\hline Butler & 2012 & -86.64125 & 31.84932 & 10 \\
\hline Butler & 2015 & -86.64416 & 31.86629 & 100 \\
\hline Chambers & 2015 & -85.48568 & 32.75863 & 0 \\
\hline Chambers & 2015 & -85.41430 & 32.86209 & 25 \\
\hline Chambers & 2015 & -85.40324 & 32.95548 & 50 \\
\hline Chambers & 2015 & -85.34948 & 33.02060 & 0 \\
\hline Choctaw & 2015 & -88.11444 & 32.11714 & 0 \\
\hline Clarke & 2012 & -87.60200 & 31.58528 & 100 \\
\hline Clarke & 2015 & -87.68589 & 31.64058 & 75 \\
\hline Clarke & 2015 & -87.78336 & 31.68193 & 75 \\
\hline Clarke & 2015 & -87.88498 & 31.54017 & 0 \\
\hline Clarke & 2012 & -87.77693 & 31.69584 & 0 \\
\hline Clarke & 2012 & -87.60114 & 31.58479 & 100 \\
\hline Clay & 2012 & -85.64930 & 33.31216 & 100 \\
\hline Clay & 2012 & -85.74929 & 33.13404 & 25 \\
\hline Clay & 2012 & -85.75622 & 32.29405 & 100 \\
\hline Clay & 2015 & -85.64930 & 33.31216 & 100 \\
\hline Clay & 2015 & -85.74929 & 33.13404 & 25 \\
\hline Coffee & 2013 & -86.15775 & 31.28032 & 100 \\
\hline Coffee & 2013 & -86.08260 & 31.29145 & 100 \\
\hline Coffee & 2013 & -85.91559 & 31.31662 & 100 \\
\hline Coffee & 2013 & -85.87160 & 31.29508 & 100 \\
\hline Coffee & 2013 & -85.83258 & 31.29854 & 100 \\
\hline Conecuh & 2012 & -86.90841 & 31.48728 & 75 \\
\hline Conecuh & 2012 & -86.91116 & 31.43800 & 75 \\
\hline Conecuh & 2012 & -86.97419 & 31.42669 & 100 \\
\hline Conecuh & 2012 & -87.19254 & 31.41929 & 100 \\
\hline Conecuh & 2012 & -87.19676 & 31.41872 & 0 \\
\hline Conecuh & 2012 & -87.06113 & 31.42159 & 0 \\
\hline Conecuh & 2015 & -86.90841 & 31.48728 & 75 \\
\hline Conecuh & 2015 & -86.91116 & 31.43800 & 75 \\
\hline Conecuh & 2015 & -86.97419 & 31.42669 & 100 \\
\hline Conecuh & 2015 & -87.19254 & 31.41929 & 100 \\
\hline Covington & 2013 & -86.26158 & 31.40273 & 25 \\
\hline Covington & 2013 & -86.27372 & 31.37176 & 87.5 \\
\hline
\end{tabular}




\begin{tabular}{|c|c|c|c|c|}
\hline \multicolumn{5}{|c|}{ TABLE 1 (continued) } \\
\hline County & Year & Longitude & Latitude & $\begin{array}{l}\% \text { inoculated } \\
\text { leaflets testing } \\
\text { positive for } \\
\text { P. pachyrhizix }\end{array}$ \\
\hline Covington & 2013 & -86.27454 & 31.35539 & 0 \\
\hline Covington & 2013 & -86.26357 & 31.32477 & 100 \\
\hline Covington & 2013 & -86.16821 & 31.28024 & 87.5 \\
\hline Crenshaw & 2013 & -86.30804 & 31.96614 & 100 \\
\hline Crenshaw & 2013 & -86.31364 & 31.95585 & 0 \\
\hline Crenshaw & 2013 & -86.31620 & 31.93470 & 75 \\
\hline Crenshaw & 2013 & -86.30049 & 31.89181 & 100 \\
\hline Crenshaw & 2013 & -86.29179 & 31.85618 & 100 \\
\hline Crenshaw & 2013 & -86.29148 & 31.76387 & 100 \\
\hline Crenshaw & 2013 & -86.26637 & 31.68729 & 87.5 \\
\hline Crenshaw & 2013 & -86.29149 & 31.76387 & 0 \\
\hline Crenshaw & 2013 & -86.24606 & 31.56206 & 100 \\
\hline Crenshaw & 2013 & -86.23651 & 31.52403 & 87.5 \\
\hline Crenshaw & 2013 & -86.26637 & 31.68729 & 0 \\
\hline Dale & 2013 & -85.67585 & 31.31226 & 75 \\
\hline Dale & 2013 & -85.60229 & 31.38341 & 100 \\
\hline Dale & 2013 & -85.61353 & 31.41917 & 87.5 \\
\hline Dale & 2013 & -85.75029 & 31.56161 & 100 \\
\hline Dallas & 2015 & -87.08010 & 32.38870 & 100 \\
\hline Dallas & 2015 & -87.23695 & 32.30776 & 100 \\
\hline Dallas & 2015 & -87.08010 & 32.38870 & 100 \\
\hline Elmore & 2015 & -85.89438 & 32.52064 & 40 \\
\hline Elmore & 2012 & -85.89008 & 32.49565 & 0 \\
\hline Elmore & 2012 & -87.47950 & 32.58639 & 0 \\
\hline Elmore & 2012 & -85.47558 & 32.58639 & 0 \\
\hline Elmore & 2012 & -85.49424 & 32.57386 & 0 \\
\hline Elmore & 2012 & -85.14740 & 32.57386 & 0 \\
\hline Elmore & 2015 & -85.87224 & 32.54546 & 100 \\
\hline Henry & 2012 & -85.31996 & 31.41271 & 0 \\
\hline Henry & 2012 & -85.47221 & 32.58617 & 30 \\
\hline Henry & 2013 & -85.27863 & 31.62697 & 25 \\
\hline Henry & 2013 & -85.27740 & 31.59893 & 0 \\
\hline Henry & 2013 & -85.28170 & 31.57510 & 75 \\
\hline Henry & 2013 & -85.29098 & 31.53439 & 0 \\
\hline Henry & 2013 & -85.31996 & 31.41271 & 0 \\
\hline Lee & 2012 & -85.48803 & 32.58060 & 0 \\
\hline Lee & 2013 & -85.50591 & 32.56130 & 0 \\
\hline Lee & 2013 & -85.49424 & 32.57386 & 0 \\
\hline Lee & 2013 & -85.50929 & 32.55336 & 0 \\
\hline Lee & 2013 & -85.52171 & 32.54137 & 0 \\
\hline Lee & 2013 & -85.54382 & 32.57376 & 12.5 \\
\hline Lee & 2013 & -85.52531 & 32.56102 & 0 \\
\hline Lee & 2013 & -85.33694 & 32.59236 & 0 \\
\hline Lee & 2012 & -85.48957 & 32.58756 & 0 \\
\hline Lee & 2013 & -85.47550 & 32.58639 & 75 \\
\hline Lee & 2013 & -85.47221 & 32.58617 & 75 \\
\hline Lee & 2013 & -85.47317 & 32.57864 & 37.5 \\
\hline Lee & 2013 & -85.47874 & 32.57949 & 25 \\
\hline Lee & 2013 & -85.54180 & 32.59364 & 0 \\
\hline Lee & 2013 & -85.50839 & 32.61006 & 0 \\
\hline Lee & 2013 & -85.50571 & 32.61922 & 0 \\
\hline Lee & 2013 & -85.37193 & 32.62571 & 0 \\
\hline Lee & 2013 & -85.34566 & 32.60605 & 0 \\
\hline Lee & 2013 & -85.29864 & 32.55483 & 0 \\
\hline Lowndes & 2012 & -86.57468 & 32.17520 & 100 \\
\hline Lowndes & 2015 & -86.55019 & 32.05046 & 100 \\
\hline Lowndes & 2012 & -86.72635 & 32.26972 & 30 \\
\hline Lowndes & 2012 & -86.75752 & 32.27716 & 60 \\
\hline Macon & 2015 & -85.75622 & 32.29405 & 10 \\
\hline Macon & 2015 & -85.54731 & 32.49684 & 100 \\
\hline Macon & 2015 & -85.57990 & 32.46782 & 100 \\
\hline
\end{tabular}

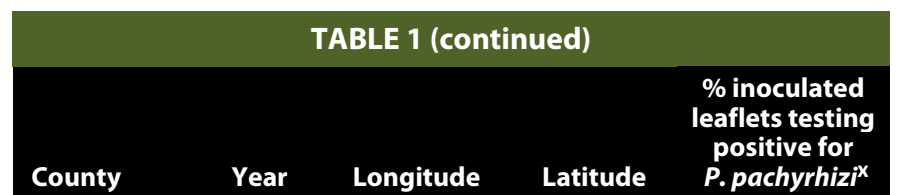

\begin{tabular}{llllr} 
Macon & 2015 & -85.64230 & 32.44640 & 100 \\
Macon & 2015 & -85.71646 & 32.40694 & 20 \\
Macon & 2015 & -85.85701 & 32.37781 & 80 \\
Marengo & 2015 & -87.65491 & 32.03392 & 60 \\
\hline Marengo & 2015 & -87.78632 & 32.05818 & 80
\end{tabular}

$\begin{array}{lllll}\text { Marengo } & 2015 & -87.78632 & 32.05818 & 80\end{array}$

$\begin{array}{lllll}\text { Marengo } & 2015 & -87.76596 & 32.19867 & 20\end{array}$

$\begin{array}{lllll}\text { Marengo } & 2015 & -87.61933 & 32.26664 & 100\end{array}$

$\begin{array}{lllll}\text { Marengo } & 2012 & -87.97730 & 32.11210 & 20\end{array}$

$\begin{array}{lllll}\text { Mobile } & 2015 & -88.01749 & 31.08700 & 75\end{array}$

$\begin{array}{lllll}\text { Mobile } & 2015 & -88.02584 & 30.99238 & 75\end{array}$

$\begin{array}{lllll}\text { Mobile } & 2012 & -88.15880 & 30.81597 & 70\end{array}$

$\begin{array}{lllll}\text { Mobile } & 2012 & -88.19938 & 30.91980 & 40\end{array}$

$\begin{array}{lllll}\text { Monroe } & 2015 & -87.38519 & 31.48940 & 100\end{array}$

$\begin{array}{lllll}\text { Monroe } & 2012 & -87.49858 & 31.51941 & 10\end{array}$

$\begin{array}{lllll}\text { Monroe } & 2012 & -87.29128 & 31.42879 & 80\end{array}$

$\begin{array}{lllll}\text { Monroe } & 2012 & -87.44185 & 31.50643 & 50\end{array}$

$\begin{array}{llllr}\text { Montgomery } & 2013 & -86.28918 & 32.02144 & 50 \\ \text { Montgomery } & 2013 & -86.29149 & 31.98680 & 0\end{array}$

$\begin{array}{llllr}\text { Montgomery } & 2013 & -86.29149 & 31.98680 & 0 \\ \text { Pike } & 2013 & -85.80569 & 31.62666 & 100\end{array}$

$\begin{array}{lllll}\text { Pike } & 2013 & -85.82790 & 31.71491 & 100\end{array}$

$\begin{array}{llllr}\text { Pike } & 2013 & -85.71538 & 31.98414 & 80\end{array}$

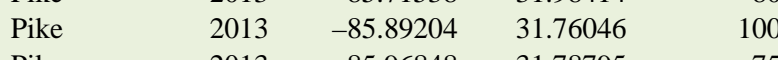

$\begin{array}{llllr}\text { Pike } & 2013 & -85.96848 & 31.78795 & 75 \\ \text { Pike } & 2013 & -85.95784 & 31.82557 & 100\end{array}$

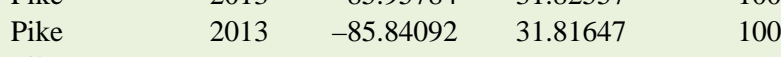

$\begin{array}{lllll}\text { Pike } & 2012 & -85.89204 & 31.76046 & 10\end{array}$

Randolph $2012 \quad-85.40723 \quad 33.18975 \quad 25$

Randolph $\quad 2015 \quad-85.36218 \quad 33.11723 \quad 0$

$\begin{array}{lrrrr}\text { Randolph } & 2012 & -85.50471 & 33.30888 & 25 \\ \text { Russell } & 2012 & -85.17924 & 32.34747 & 100\end{array}$

Russell $\quad 2012 \quad-85.17130 \quad 32.11315 \quad 0$

$\begin{array}{lrrrr}\text { Russell } & 2013 & -85.17195 & 32.30000 & 0 \\ \text { Russell } & 2013 & -85.17130 & 32.11315 & 100\end{array}$

$\begin{array}{lrrrr}\text { Russell } & 2013 & -85.17130 & 32.11315 & 100 \\ \text { Russell } & 2013 & -85.17924 & 32.34747 & 30\end{array}$

$\begin{array}{lllll}\text { Russell } & 2012 & -85.33694 & 32.59236 & 0\end{array}$

Russell $\quad 2013 \quad-85.18923 \quad 32.40083$

Russell $\quad 2012 \quad-85.18923 \quad 32.40083$

Russell $\quad 2013 \quad-85.18505 \quad 32.37006$

$\begin{array}{llll}\text { Sumter } & 2012 & -88.18961 & 32.36031\end{array}$

Tallapoosa $\quad 2015 \quad-85.87224 \quad 32.54546$

Washington $2012 \quad-87.97923 \quad 31.49948$

Wilcox $\quad 2015 \quad-86.91171 \quad 31.99211$

Wilcox $\quad 2015 \quad-86.99848 \quad 32.00682$

Wilcox $\quad 2015 \quad-87.09767 \quad 31.98437$

Wilcox $\quad 2015 \quad-87.28701 \quad 31.99202$

$\begin{array}{llll}\text { Wilcox } & 2015 & -87.53231 & 31.97918\end{array}$

Wilcox $\quad 2012 \quad-87.60654 \quad 32.00899$

Wilcox $\quad 2012 \quad-87.28333 \quad 32.00126$

$\begin{array}{llll}\text { Wilcox } & 2012 \quad-87.00548 \quad 32.00577\end{array}$

x Minimum of 10 leaflets inoculated in 2012; eight leaflets in 2013; and five leaflets in 2015. Scoring was determined by the presence or absence of pustules with spores on the leaf surface.

In their distribution across the sampled areas, there was no consistent pattern of resistant sites (Fig. 5). This trend was also observed by Jordan et al. (2010) for kudzu patches in North Florida, and by Bonde et al. (2009) in Kentucky, Louisiana, Mississippi, and North Carolina. This result was not unexpected based on the genetic diversity observed among kudzu populations. Sun et al. (2005) reported that kudzu populations in the south-

(continued) 
eastern United States were genetically diverse among populations, but had little diversity within populations, indicating multiple introductions with inbreeding within these populations. However, there was at least one case where SBR-resistant kudzu populations appeared to be grouped together in a single county. This was observed in 2015 when four of five kudzu populations sampled from Wilcox County were determined to be resistant to $P$. pachyrhizi. There were other instances where populations located within a few miles of one another were also observed to be resistant to the pathogen. It is possible this goes back to how these populations were first established in the state. In the 1930s, the Soil Conservation Service employed hundreds of people in the Civilian Conservation Corps to plant kudzu for erosion control (Britton et al. 2002; Everest et al. 1999). It is likely that kudzu with a similar genotype was planted in clusters across the south, with further spread locally by birds and animals.

\section{MAPPING KUDZU POPULATIONS SAVE TIME AND MONEY}

Results from our study show that approximately $34 \%$ of kudzu sites in south and central Alabama are resistant to P. pachyrhizi. Mapping these sites using GPS coordinates along with marking kudzu patches susceptible to the disease will enable scouts to focus their efforts on areas more likely to exhibit early symptoms of SBR. This increased efficiency will result in a cost-savings to the monitoring program.

Historically, monitoring the sites outlined in this study involves having two scouts traveling in one vehicle once a week for 24

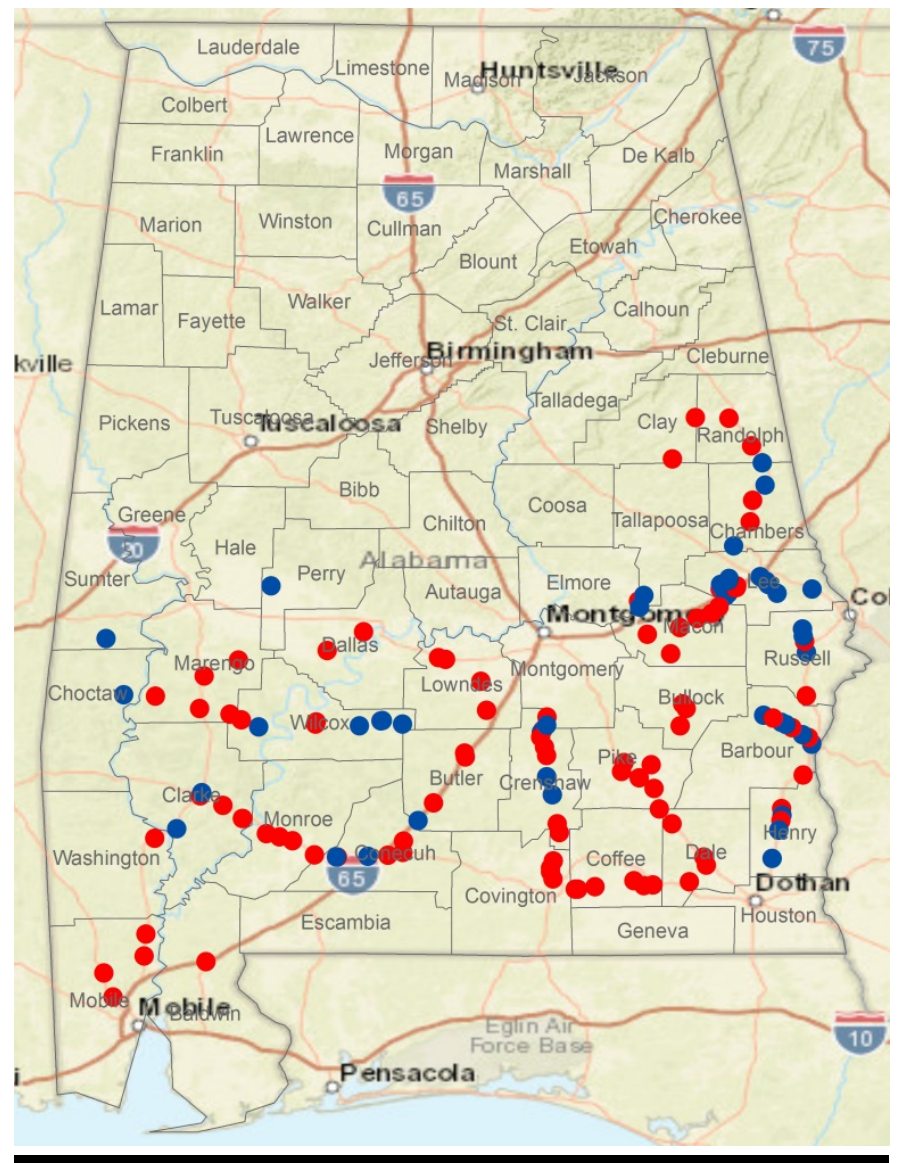

\section{FIGURE 5}

Map of Alabama showing locations of 162 kudzu populations in 30 southern counties marked SBR-susceptible/positive (red) or SBRresistant/negative (blue) by GPS coordinates. weeks (late January through the end of July) on an approximately 300 mile journey that alternates between two set circular routes and takes $13 \mathrm{~h}$ to complete on average. The total cost to the SBR monitoring program for this 24 -week period at this time comes to $\$ 7,375.44$, which includes a $\$ 30$ per diem, $\$ 0.54$ in mileage reimbursement, and $\$ 188.50$ in wages (@ $\$ 7.25 /$ hour). Using our new GPS coordinates of confirmed SBR-susceptible kudzu sites, we have been able to reduce our total cost to $\$ 5,525.16$ by requiring only one person to complete each scouting mission. By eliminating the per diem and wages for one individual, we have reduced our costs by approximately $25 \%$ for this portion of the SBR monitoring program in Alabama. These numbers will vary from year to year depending on various factors such as fluctuation in the movement of SBR within the state and/or how early the pathogen is detected in a county. Typically, when environmental conditions favor the rapid spread of SBR in Alabama, it can often be observed in multiple locations and counties in a single day. In our program, we rarely return to a county to scout for SBR after the disease has been detected. At that point, we have shifted our focus to soybean sentinel plots and commercial soybean fields in the central and northern sections of the state.

The ability to scout kudzu from late January through the end of July is a vital component of the SBR monitoring program in Alabama. By conducting this project, we have identified and mapped the location throughout central and south Alabama of kudzu populations that are susceptible or resistant to $P$. pachyrhiza. In doing so, we have increased our efficiency in monitoring for the disease and reduced the cost associated with the scouting program, thus potentially making the program more sustainable. This is important, as the funding available for SBR monitoring has declined significantly since 2005 (Allen et al. 2014; Sikora et al. 2014).

\section{ACKNOWLEDGMENTS}

This project was supported with funding from the Alabama Soybean Producers. We also thank Dr. Tom Allen from Mississippi State University for his thorough review of this manuscript.

\section{LITERATURE CITED}

Alabama Cooperative Extension System. 2013. Making a difference in every corner of the state. 2012 Annual Report, ACES-0001. Auburn, AL. http://www.aces.edu/pubs/docs/A/ACES-0001/ACES-0001.pdf.

Allen, T. W., Hollier, C. A., and Sikora, E. J. 2014. A continuing saga: Soybean rust in the continental United States, 2004 to 2013. Outlooks Pest Manage. 25:167-174.

Bonde, M. R., Nester, S. E., Moore, W. F., and Allen, T. W. 2009. Comparative susceptibility of kudzu accessions from the southeastern United States to infection by Phakopsora pachyrhizi. Plant Dis. 93:593-598.

Britton, K. O., Orr, D., and Sun, J. 2002. Kudzu. Pages 325-326 in: Biological Control of Invasive Plants in the Eastern United States. R. Van Driesche, ed. USDA Forest Service Publ. FHTET-2002-04. Washington, DC

Everest, J. W., Miller, J. H., Ball, D. M., and Patterson, M. 1999. Kudzu in Alabama history, uses, and control. Alabama Coop. Ext. System (ACES), ANR-65. Auburn, AL.

Giesler, L. J., and Hershman, D. E. 2005. Overview and value of sentinel plots for 2005. Proc. 2nd Nat. Soybean Rust Sym. American Phytopathology Society, St. Paul, MN.

Hershman, D. E., Sikora, E. J., and Giesler, L. J. 2011. Soybean Rust PIPE: Past, present, and future. J. Integr. Pest Manage. doi:10.1603/IPM11001.

Jordan. S. A., Mailhot, D. J., Gevens, A. J., Marois, J. J., Wright, D. L., Harmon, C. L., and Harmon, P. F.. 2010. Characterization of kudzu (Pueraria spp.) resistance to Phakopsora pachyrhizi, the causal agent of soybean rust. Phytopathology 100:941-948.

Miller, J. H., and Edwards, B. 1983. Kudzu: Where did it come from and how can we stop it? South. J. Appl. For. 7:165-169. 
Mullen, J. M., Sikora, E. J., McKemy, J. M., Palm, M. E., Levy, L., and Devries-Paterson, R. 2006. First report of Asian soybean rust caused by Phakopsora pachyrhizi on soybeans in Alabama. Plant Dis. 90:112.

Oke, T. R. 1997. Urban climates and global change. Pages 273-287 in: Applied Climatology: Principles \& Practices. R. D. Thompson and A. Perry, eds. Routledge, London, UK.

Price, C. 2016. Alabama county estimates: Soybeans 2014-2015. USDANASS, Washington, D.C. http://www.nass.usda.gov.

Schneider, R. W., Hollier, C. A., Whitam, H. K., Palm, M. E., McKemy, J. M., Hernandez, J. R., Levy, L., and Devries-Patterson, R. 2005. First report of soybean rust caused by Phakopsora pachyrhizi in the continental United States. Plant Dis. 89:774.

Sikora, E. J. 2014. Kudzu: Invasive weed supports the soybean rust pathogen through winter months in southeastern United States. Outlooks Pest Manage. 25:175-179.

Sikora, E. J., Allen, T. W., Wise, K. A., Bergstrom, G., Bradley, C. A., Bond, J., Brown-Rytlewski, D., Chilvers, M., Damicone, J., DeWolf, E., Dorrance, A., Dufault, N., Esker, P., Faske, T. R., Giesler, L., Goldberg, N., Golod, J., Gomez, I. R. G., Grau, C., Grybauskas, A., Franc, G., Hammerschmidt, R., Hartman, G. L., Henn, A., Hershman, D., Hollier, C., Isakeit, T., Isard, S., Jacobson, B., Jardine, D., Kemerait, B., Koenning, S., Langham, M., Malvick, D., Markell, S., Marois, J. J., Monfort, S., Mueller, D., Mueller, J., Mulroony, R., Newman, M.,
Osborne, L., Padgett, G. B., Ruden, B. E., Rupe, J., Schneider, R., Schwartz, H., Shaner, G., Singh, S., Stromberg, E., Sweets, L., Tenuta, A., Vaiciunas, S., Yang, X. B., Young-Kelly, H., and Zidek, J. 2014a. A coordinated effort to manage soybean rust in North America: A success story in soybean disease monitoring. Plant Dis. 98:864-875.

Sikora, E. J., Conner, K. Delaney, D., Zhang, L., and Delaney, M. 2014b. Observations on soybean rust and soybean vein necrosis virus in Alabama in 2013. Page 14 in: Proc. Southern Soybean Dis. Workers. 41st Annu. Meeting.

Sikora, E. J., Delaney, D., and Delaney, M. 2009. Developing an innovative team approach to address a newly introduced disease of soybeans in the United States. JOE 47:4IAW7.

Sikora, E. J., Delaney, D. P., and Delaney, M. 2013. Observations on soybean rust management in Alabama in 2012. Page 13 in: Proc. Southern Soybean Dis. Workers. 40th Annu. Meeting.

Sikora, E., and Hershman, D. 2008. Soybean rust in review: 2004-2007. Pages 20-28 in: Using Foliar Fungicides to Manage Soybean Rust. A. E. Dorrance, M. A. Draper, and D. E. Hershman, eds. NC-504 Land-Grant Univ. Coop. SR-2008. http://oardc.osu.edu/soyrust/.

Sun, J. H., Li, Z. C., Jewett, D. K., Britton, K. O., Ye, W. H., and Ge, X. J. 2005. Genetic diversity of Pueraria lobata (kudzu) and closely related taxa as revealed by inter-simple sequence repeat analysis. Weed Res. 45:255-260. 